\title{
Julius Africanus, Origen, and the Politics of Intellectual Life under the Severans"
}

\author{
JARED SECORD
}

\begin{abstract}
The prominence gained by two Christian scholars, Julius Africanus and Origen, under the Severan dynasty and the connections to the imperial household that they enjoyed cannot be explained simply as a consequence of newfound imperial interest in Christianity, contrary to the prevailing scholarly consensus. The successes of Africanus and Origen were instead a result of their ability to gain mainstream legitimacy among the empire's intellectual elite, something that no earlier Christian scholars had achieved. Unlike earlier Christian scholars, Africanus and Origen were able to gain legitimate status because they had ready access to money to support their education and research. They were also basically indistinguishable from non-Christian scholars in their ability to serve and interact with the imperial household.
\end{abstract}

\section{Introduction}

Under the Severans, Julius Africanus and Origen achieved levels of prominence unmatched by any previous Christian scholar, gaining connections even to the imperial household during the reign of Alexander Severus (222-235 CE). ${ }^{1}$ Christian scholars in earlier periods had attempted to

"I wish to express thanks to the audience and other participants at the APA panel wherea draft of this paper was delivered, and to the participants of the Ancient Societies Workshop at the University of Chicago, who provided helpful feedback on my arguments about Africanus and the library of the Pantheon. Abbreviations follow those given in the $O C D$. For authors and texts not included in this list, references will be given in unabbreviated form, with the exception of the works of Galen, which will be abbreviated following the list given in R. J. Hankinson, ed., The Cambridge Companion to Galen (Cambridge 2008) 391-97. All translations are my own.

${ }^{1}$ A third Christian scholar, Hippolytus of Rome, also seems to have gained a connection to the imperial household under the Severans. He dedicated a work On the Resurrection to Julia Mamaea, the mother of Alexander Severus. Fragments of the work are collected in H. Achelis, Hippolyt's kleinere exegetische und homiletische Schriften,

Classical World, vol. 110, no. 2 (2017) Pp.211-235 
attract attention to themselves, and had been successful to varying degrees, but the Severan dynasty represented a major breakthrough. ${ }^{2}$ Explanations for the new prominence of Christianity and Christian scholars have tended to emphasize as a basic factor the Eastern connections of the Severan dynasty and the supposed sympathy of its members towards Christianity. Recent scholarship has admittedly backed away from older and more extreme suggestions about the spread of Eastern cults thanks to the influence of the Severans, ${ }^{3}$ but wide-ranging claims are still often made about the ability of Christians to take advantage of the dynasty's "syncretic," "henotheistic," or "universalizing" tendencies. ${ }^{4}$ Such claims, I shall argue, take too much for granted about the backgrounds of Africanus and Origen, and the nature of their relationships with Alexander and his mother, Julia Mamaea. Lurking behind these claims is the assumption that the Christianity of Africanus and Origen was the decisive, or at least an extremely significant, factor in their relationship with Alexander and Mamaea. In the process, the great similarities that Africanus and Origen had with their non-Christian scholarly contemporaries

GCS 1.2 (Leipzig 1897) 251-54; M. Richard, "Quelques nouveaux fragments des pères anténicéens et nicéens," Symbolae Osloenses 38 (1963) 79-80; there is additional discussion in H. Achelis, Hippolytstudien, TU 16.4 (Leipzig 1897) 189-94. As much as I would like to include more detailed discussion of Hippolytus and his connections to the imperial household, there are insoluble problems about his biography and the large corpus of works attributed to him. For a sensible attempt to deal with some of these problems, see J. A. Cerrato, Hippolytus between East and West: The Commentaries and the Provenance of the Corpus (Oxford 2002).

${ }^{2}$ See T. D. Barnes, "Aspects of the Severan Empire, Part II: Christians in Roman Provincial Society," NECJ 36.1 (2009) 3-19. Barnes suggests that Christians were able to achieve "both respectability and a large measure of de facto toleration in Roman society" before the end of the Severan dynasty.

${ }^{3}$ B. Levick, Julia Domna: Syrian Empress (London and New York 2007) 163. See also the overview of older scholarship in C. Rowan, Under Divine Auspices: Divine Ideology and the Visualisation of Imperial Power in the Severan Period (Cambridge 2012) 9-10.

${ }^{4}$ See M. Mazza, "Le religioni dell'Impero Romano. Premesse ad una considerazione storica della religiosità ellenistico-romana," in Storia letteratura e arte a Roma nel secondo secolo dopo Cristo: atti del convegno : Mantova 8-9-10 ottobre 1992 (Florence1995) 131, 135-36; E. Sanzi, "Sincretismo e tolleranza religiosa dell'età dei Severi: Per una tipologia storico-religiosa dei culti orientali del secondo ellenismo," SMSR 24 (2000) 109-44; K. Burasaelis, $\Theta \varepsilon i ́ \alpha \delta \omega \rho \varepsilon \alpha$. Das göttlich-kaiserliche Geschenk: Studien zur Politik der Severer und zur Constitutio Antoniniana, Akten der Gesellschaft für Griechische und Hellenistische Rechtsgeschichte 18, tr. W. Schürmann (Vienna 2007) 39-47; U. Roberto, Le Chronographiae di Sesto Giulio Africano: Storiografia, politica e cristianesimo nell'età dei Severi (Rome 2011) 125, 170. 
are glossed over, and their ability to fit into elite, mainstream intellectual life is ignored or minimized. ${ }^{5}$ My goal in this paper is to establish the mainstream intellectual credentials of Africanus and Origen, and to suggest that Christianity had relatively little bearing on the connections they gained to the imperial household. ${ }^{6}$ Ultimately, as I shall argue, the unprecedented successes enjoyed by Africanus and Origen should be taken as signs of the increasing ability of Christian scholars to be recognized as legitimate within mainstream circles and not simply as a consequence of the imperial household's sympathy to Christianity.

The successes of Africanus and Origen depended on two factors: their access to wealth and their ability to live up to the same standards that applied to elite, non-Christian scholars. I argue below that Africanus and Origen had more money at their disposal than did most earlier Christian scholars, and that their access to wealth allowed them not only to receive additional education but also to fund the major projects which they undertook. Money provided the basis for their scholarly reputations and helped them to live up to the demanding expectations for scholars familiar to us from the works of Galen and Philostratus. As I also argue in the paper's next section, Africanus and Origen both fit in quite well with the scholarly world depicted by these two scholars, and better than nearly every previous Christian scholar. Their ability to fit in among non-Christian scholars was especially important to Alexander and Mamaea, who were both eager to establish their own mainstream legitimacy, and to distance themselves from the dynasty's reputation for foreignness. In this sense, it is especially noteworthy that Africanus'

${ }^{5}$ There have already been some attempts to place Africanus within the context of the "Second Sophistic." See W. Adler, "The Cesti and Sophistic Culture in the Severan Age," in M. Wallraff and L. Mecella, eds., Die Kestoi des Julius Africanus und ihre Überlieferung, TU 165 (Berlin and New York 2009) 1-15; Roberto (above, n.4) 24-25, 43-44. Note also E. D. Digeser (A Threat to Public Piety: Christians, Platonists, and the Great Persecution [Ithaca 2012] 49-71) for discussion of Origen within the larger context of third-century philosophical schools; N. McLynn ("Roman Empire," in J. A. McGuckin, ed., The Westminster Handbook to Origen [Louisville and London 2004] 185) for the suggestion that Origen "more resembles contemporary intellectuals than his fellow Christians" in terms of "his experience of the actuality of empire." K. Eshleman (The Social World of Intellectuals in the Roman Empire: Sophists, Philosophers, and Christians [Cambridge 2012] 14) suggests that "Christian intellectuals were closer in background and habitus to Second Sophistic pepaideumenoi than either would have liked to admit."

${ }^{6}$ W. Adler ("Sextus Julius Africanus and the Roman Near East in the Third Century," JThS 55.2 [2004] 540-41) suggests that Afrianus' connections with Alexander had little to do with Christianity. 
connections to Alexander seem to have had little to do with Christianity. Africanus' skills and training allowed him to fit into a variety of roles that non-Christian scholars had been fulfilling for the imperial household for centuries. He was an ambassador, a librarian, and likely even an architect, and he possessed also a range of literary skills that made him comparable to his non-Christian contemporaries. Origen, meanwhile, was a capable extemporaneous speaker with a histrionic manner and fascinating stage presence, much like many contemporary sophists; his behavior and self-presentation would have been quite familiar to Mamaea when they met. Besides the fact that they were Christians, both Africanus and Origen were almost indistinguishable in their overall profiles from the many others scholars who served the imperial household in earlier periods and under the Severans. Ultimately, the prominence gained by Africanus and Origen under the Severans had less to do with changing attitudes towards religion and Christianity and more to do with their training and reputations as scholars that allowed them to gain mainstream legitimacy.

\section{Money, Education, and Christian Scholarship}

The significance of wealth for the successful careers of Africanus and Origen cannot be overstated. Without the funds that they had to support their education and scholarly careers, they would have faced insurmountable difficulties in building reputations as legitimate scholars. Their access to wealth is something that differentiated them from most earlier Christian scholars. While there were a few Christian scholars of the second century who seem to have been reasonably wealthy, or to have at least had connections to a wealthy patron, most Christian scholars in this period were considerably poorer than Africanus and Origen. ${ }^{7}$ The ambitions of these scholars to achieve mainstream success were

${ }^{7}$ One example is Ptolemy, the author of a letter to a certain Flora (quoted in Epiph. Adv. haeres. 33.3-7), who seems to have been his aristocratic patron. See I. Dunderberg, Beyond Gnosticism: Myth, Lifestyle, and Society in the School of Valentinus (New York 2008) 77-94. Another is Marcion, who was a captain in the imperial grain trade (see Tert. De praescr. haeret. 30.1; P. Lampe, From Paul to Valentinus: Christians at Rome in the First Two Centuries, M. Steinhauser, tr., M. D. Johnson, ed. [Minneapolis 2003] 241-52), and who famously donated 200,000 HS to the Roman church in 144 (Tert. De praescr. haeret. 30.2). A third is Athenagoras, a Christian scholar from Athens who has been taken by some to be exceptionally learned, though many details about his life and the attribution 
hampered by a lack of funds, something that was not the case for Africanus and Origen under the Severans.

Two examples drawn from the careers of earlier Christian scholars with limited funds serve to illustrate the advantages that Africanus and Origen had over them. The first of these comes from the school of Justin Martyr, who was active at Rome in the middle decades of the second century. ${ }^{8}$ A lack of money in Justin's family seems to have limited the education that he was able to receive in his youth. As he explains, he was rejected as a prospective student by a Pythagorean teacher because of his inadequate training: "What! Haven't you become familiar with music, astronomy, and geometry?"' These three areas of study were regarded as essential preparatory subjects by many scholars in the period, as is apparent especially from the works of Galen, who heaped considerable scorn on anyone without training in them. ${ }^{10}$ Justin would thus have been at a considerable disadvantage for his entire career because of the incomplete education that he received in his youth. Justin's later career in Rome was also harmed by a lack of money. The location of his school at Rome points to his relative poverty: it was in a rented room above a public bath. ${ }^{11}$ Justin evidently had no patron to provide him with better lodgings, and it is difficult to believe that he owned property at Rome, as did several elite scholars of the second century, such as Favorinus, Herodes Atticus, and Galen. ${ }^{12} \mathrm{He}$ dressed in a philosopher's

of works to him are contested. See D. Rankin, Athenagoras. Philosopher and Theologian (Farnham and Burlington 2009) 1-16.

${ }^{8}$ For an overview of Justin's life and education, see Lampe (above, n.7) 257-84.

9 Justin, Dialogus cum Tryphone 2.4; M. Marcovich, ed., Iustini Martyris Dialogus cum Tryphone (Berlin and New York 1997). Lampe (above, n.7) 258 n.4 defends the authenticity of Justin's story, which has often been doubted.

${ }^{10}$ E.g. Libr. Propr. 11 (Kühn 19.40-41); Opt. Doct. 1 (Kühn 1.53); Pecc. Dig. 2.8 (Kühn 5.64); MM 1.1, 2, 3 (Kühn 10.4-5, 17, 30). Lampe (above, n.7) 258 n.1 collects many other references from second-century authors insisting on the importance of geometry and mathematics, without including Galen.

${ }^{11}$ See Martyrium Sancti Iustini et Sociorum, 3 (recension A and B; H. Musurillo, ed., The Acts of the Christian Martyrs [Oxford 1972]). H. G. Snyder ("'Above the Bath of Myrtinus': Justin Martyr's 'School' in the City of Rome," HTR 100.3 [2007] 335-62) discusses an attempt to locate Justin's school more precisely with reference to the Severan marble plan. This is dismissed as speculative by T. Georges, "Justin's School in Rome-Reflections on Early Christian 'Schools'," ZAC 16 (2012) 79 n.21. See also J. Ulrich, "What Do We Know about Justin's 'School' in Rome?" ZAC 16 (2012) 62-74.

${ }^{12}$ For Favorinus and Herodes Atticus, see Philostr. VS 1.23 (489). For Galen's houses in Rome, see V. Boudon-Millot, Galien de Pergame: Un médecin grec à Rome 
cloak and addressed his Apology to Antoninus Pius, Marcus Aurelius, and Lucius Verus, but it and his other works suggest that he had difficulty attracting the attention of non-Christian scholars..$^{13}$ Evidently, the only philosopher willing to engage with Justin and his pupils was a Cynic named Crescens, who seemed more interested in ridiculing his teachings than participating in a real debate. ${ }^{14}$ With his incomplete education, and a continuing lack of money in his later career, Justin and his pupils struggled to attract the attention of non-Christian scholars, despite their best efforts.

Much the same can be said about the second example, the school established by Theodotus of Byzantium at Rome, which was active in the late-second and early third centuries. ${ }^{15}$ Theodotus and his followers had serious intellectual pretensions. According to a later heresiologist their

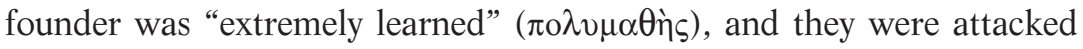
by a contemporary rival for their interests in Aristotle, Theophrastus, Euclid, and Galen. ${ }^{16}$ The reference to Euclid suggests that they had the geometrical and mathematical training that Justin lacked. Yet even with their additional education, Theodotus and his followers had other barriers and

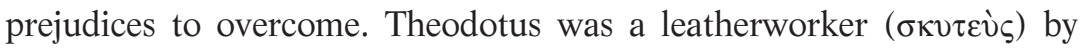
profession, and his pupil of the same name was a banker ( $\left.\tau \rho \alpha \pi \varepsilon \zeta^{i} \tau \eta \zeta\right) .{ }^{17}$ The latter trade was undoubtedly more profitable than the former, but

(Paris 2012) 202-204; S. Mattern, The Prince of Medicine: Galen in the Roman Empire (Oxford 2013) 183.

${ }^{13}$ Cloak: Dialogus cum Tryphone 1.2, 9.2. Address to the emperors: Apol. 1.1; D. Minns and P. Parvis, eds., Justin, Philosopher and Martyr: Apologies (Oxford 2009).

${ }^{14}$ See Apol. 2.8(3).1-7, 2.11.2; Tatian, Ad Gr. 19.3. Lampe (above, n.7) 275 suggests that Justin debated with other philosophers, but none of the passages he cites as evidence demonstrate this.

${ }^{15}$ See the overview in Lampe (above, n.7) 344-48; J. Secord, "Galen and the Theodotians: Embryology and Adoptionism in the Christian Schools of Rome," Studia Patristica (forthcoming).

${ }^{16}$ Epiph. Adv. haeres. 54.1.3; Euseb. Hist. eccl. 5.28.14. Eusebius draws his information from a work called The Little Labyrinth written by an unidentified author active at Rome in the early third century. See J. T. Fitzgerald, "Eusebius and the Little Labyrinth," in A. J. Malherbe, F. W. Norris, and J. W. Thompson, eds., The Early Church in its Context: Essays in Honor of Everett Ferguson (Leiden 1998) 120-46.

${ }^{17}$ For Theodotus' profession, see Epiph. Adv. haeres. 54.1.3; Euseb. Hist. eccl. 5.28.6, 9. As O. Lau ("Schuster und Schusterhandwerk in der griechisch-romischen Literatur und Kunst," Ph.D. diss., Rheinischen Friedrich-Wilhelms-Universität zu Bonn [1967]

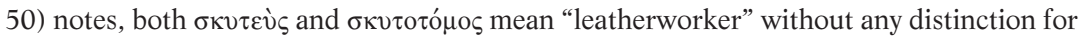
the various types of activities that might be involved in the trade. For his pupil's profession, see Euseb. Hist. eccl. 5.28.9; [Hippol.] Haer. 7.36.1. Note also Theodoret, Haereticarum 
neither had a good reputation among elite scholars. ${ }^{18}$ Just before the time of Theodotus, the philosopher Celsus had harsh words against the activities of Christian teachers, whom he labeled as "wool-workers, shoemakers, fullers, and the most uneducated and rustic individuals." ${ }^{19}$ This banausic and uneducated group confined their activities, Celsus charged, to the relative privacy of the "women's quarters, or the shoemaker's or fuller's shop," and they dared not engage with better-educated scholars in public. ${ }^{20}$ Besides the prejudice that they faced, Theodotus and his followers had a relatively small amount of money to support their activities. From a contemporary rival we know that they hired a bishop and paid him a monthly salary of 150 denarii $(=600$ sesterces $) .{ }^{21}$ This amounted to an annual salary of $7,200 \mathrm{HS}$, which is a pittance compared to the sums that supported the activities of elite scholars in the same period. ${ }^{22}$ Apuleius, for instance, split an inheritance of two million sesterces with his brother and depleted his share by traveling and furthering his education. ${ }^{23}$ However ambitious Theodotus and his followers may have been, a lack of funds hindered the progress of their careers and prevented them from being recognized as legitimate scholars and from breaking through into the mainstream of intellectual life at Rome.

Africanus and Origen faced no such difficulties. The money that provided the basis for their careers is more or less obviously apparent behind all of the evidence that we have for their lives. To take Africanus first, much is unknown about his life and background, but all signs suggest that he was a member of the local elite in the city of his birth, Colonia Aelia Capitolina, the former Jerusalem. ${ }^{24}$ His tria nomina, Sextus

Fabularum Compendium 2.6 ( $P G$ 83.393a), where he is identified as a "money changer"

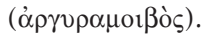

${ }^{18}$ See J. Andreau, Banking and Business in the Roman World, tr. J. Lloyd (Cambridge 1999) 4 for the characterization of bankers as "small-scale entrepreneurs."

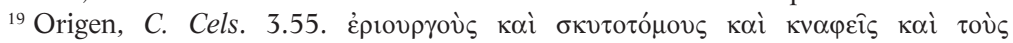

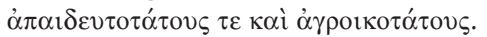

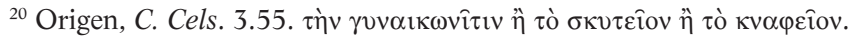

${ }^{21}$ Euseb. Hist. eccl. 5.28.10. Theodoret (Haereticarum Fabularum Compendium 2.5 [PG 83.392b]) suggested that it was a daily, rather than a monthly, salary!

${ }^{22}$ Note Lampe (above, n.7) 346, on the salary: "It is a considerable sum, although not extravagant."

${ }^{23}$ See Apul. Apol. 23.1-2. Compare Galen, who proudly put to good use the inheritance he received from his father: Aff. Dig. 1.9.10 (Kühn 5.48).

${ }^{24}$ Africanus identifies his place of birth at Cesti F10.50-1 (M. Walraff, et al., eds. . Iulius Africanus. Cesti. The Extant Fragments, tr. W. Adler (Berlin and New York 2012) = 
Julius Africanus, demonstrate his status as a Roman citizen, and that he or someone in his family received this status before Caracalla's decree..$^{25}$ Fragments of his works reveal that he was an accomplished traveler, especially in the provinces of the Roman Near East and Asia Minor. Before he came to Rome, he had already visited Alexandria and the Dead Sea and spent time at the court of King Abgar the Great (177-212 CE) in Edessa. ${ }^{26} \mathrm{He}$ had even gone in search of the place where Noah's Ark had landed, travelling to Ararat in Parthia and Celaenae in Phrygia. ${ }^{27}$ During his travels, Africanus undertook archival research and acquired rare books that he came across, such as a copy of the Sacred Book of the Pharaoh Suphis in Alexandria. ${ }^{28}$ All of these travels speak to Africanus' access to wealth and his elite status. The learning displayed in his works provides signs also of the quality and the breadth of the education that he had received. Forays into Homeric criticism sit side-by-side with his close engagement with Herodotus. ${ }^{29}$ Africanus possessed training also in the preparatory subjects that Justin lacked, and he was eager to advertise this fact. As he remarked, in a notable display of false modesty, "Those who have gained a middling general education, it stands to reason, have touched on the Elements of Euclid to some degree." ${ }^{30}$ Even in the absence of more details about Africanus' life, the fragments of his

POxy. 3.412. See Roberto (above, n.4) 30-33 for discussion of Africanus' elite status, and speculation that his family may have belonged to the equestrian order.

${ }^{25}$ Against previous doubts concerning the praenomen Sextus, see Adler (above, n.6) 523-24; Roberto (above, n.4) 32-33.

${ }^{26}$ Alexandria: Chronographiae F98 (M. Wallraff, ed., Iulius Africanus Chronographiae. The Extant Fragments with the assistance of U. Roberto and K. Pinggéra, tr. W. Adler [Berlin and New York 2007]) = Euseb. Hist. eccl. 6.31.2. The Dead Sea: Chronographiae F26.13-22 = Syncellus, Ecloga chronographica, 114.13-24 (A. A. Mosshammer, ed., Georgius Syncellus. Ecloga chronographica [Leipzig 1984]). Edessa: Cesti F12.20, with discussion in Roberto (above, n.4) 46-57.

${ }^{27}$ Chronographiae F23.18-20 = Syncellus, Ecloga chronographica, 22.6-8.

${ }^{28}$ Suphis' book Chronographiae F46.52-55 = Syncellus, Ecloga chronographica, 63.2-6. Note also the reference to the still circulating copies of the books on anatomy of the Pharaoh Athothis: Chronographiae F46.5-6 = Syncellus, Ecloga chronographica, 61.11-12. Archival visits in Colonia Aelia Capitolina and Nysa: Cesti F10.49-53 = P.Oxy. 3.412. Note also another possible reference to Africanus' archival research in Edessa (Chronographiae T88 = Moses of Chorene 2.10), which is treated skeptically by Walraff (above, n.26) xlviii, $261 \mathrm{n} .1$, but accepted by Roberto (above, n.4) 56.

${ }^{29}$ Homeric criticism: Cesti F10 = P.Oxy. 3.412. Engagement with Herodotus: Cesti F75 = Vaticanus gr. 284, fol. 288v, and Walraff (above, n.24) xxv.

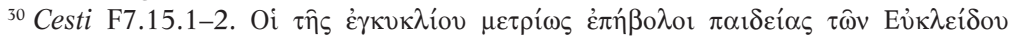

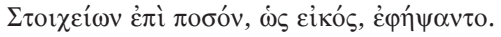


works demonstrate his privileged background and access to wealth. Unlike previous Christian scholars, there were no serious barriers relating to wealth or status that Africanus had to overcome in order to achieve mainstream legitimacy.

The same was true for Origen, for whom we have many more biographical details to confirm his access to wealth. Doubts have been raised about many elements of these biographical details, especially by Pierre Nautin, but such doubts have little bearing on the general argument offered here about his family background and education. ${ }^{31}$ There has also been major controversy surrounding the possibility that there were two different scholars named Origen, one a Platonist and a pupil of Plotinus' teacher Ammonius Saccas, and the other a Christian and pupil of a different philosopher named Ammonius. ${ }^{32}$ The details of this controversy are beyond the scope of this paper, and I will only state briefly that I follow the arguments of Nautin and Elizabeth DePalma Digeser that there was only one Origen, and only one Ammonius. ${ }^{33}$ Regardless of the position that one takes in this controversy, it is still abundantly clear that Origen was exceptionally well-educated, and that his education depended first on the support of his family and subsequently of a patron. His father, martyred when Origen was young, likely possessed the training of a grammarian, and he may well also have been a Roman citizen, to judge from Eusebius' suggestion that he was beheaded, a punishment reserved for citizens. ${ }^{34}$ After his father's death in 202/3, Origen's education continued thanks to the generosity of an unnamed wealthy woman in Alexandria. ${ }^{35}$ Origen's father and this woman ensured that he received an excellent general education along with special training as a grammarian. ${ }^{36}$ Origen put all of this education to use in his later career as a

${ }^{31}$ P. Nautin, Origène: Sa vie et son oeuvre (Paris 1977).

${ }^{32}$ For defenses of the thesis that there were two different scholars named Ammonius and Origen, see F. M. Schroeder, "Ammonius Saccas," ANRW 2.36.1 (1987) 493-526; M. Edwards, "Ammonius, Teacher of Origen," JEH 44 (1994) 169-81; R. E. Heine, Origen: Scholarship in the Service of the Church (Oxford 2010) 24.

${ }^{33}$ See Nautin (above, n.31) 197-202; Digeser (above, n.5) 49 n.1, with extensive references to previous scholarship on the issue.

${ }^{34}$ Euseb. Hist. eccl. 6.1.2. Nautin (above, n.31) 32 doubts that the name of Origen's father was really Leonides, as Eusebius claims. See Heine (above, n.32) 20 and Digeser (above, n.5) 51 for discussion of the social status and education of Origen's father.

${ }^{35}$ Euseb. Hist. eccl. 6.2.13. For the date, see Digeser (above, n.5) 51 with further references.

${ }^{36}$ See Euseb. Hist. eccl. 6.2.7, 14. 
teacher. We know from multiple sources that he instructed his students in the same group of preparatory subjects that Justin had earlier lacked: geometry, music, grammar, rhetoric, and astronomy. ${ }^{37}$ Origen received additional patronage in his later career from Ambrose, a man of immense wealth who, in Jerome's words, "furnished him with parchment (chartas), funds, and copyists" and thus allowed his client to produce his "innumerable books." ${ }^{38}$ Ambrose took a personal interest also in his client's labors, working and listening to dictation with him without cease, and even offering advice and corrections when Origen was writing a letter to Africanus. ${ }^{39}$ The major projects that Origen undertook would have been impossible without the funds and clerical support staff provided by Ambrose. ${ }^{40}$ One of these projects alone, the Hexapla, which presented the text of the Hebrew Bible alongside different Greek translations, would have cost roughly 150,000 denarii $(=600,000$ sesterces) to have a single copy produced on parchment, according to the estimates of Anthony Grafton and Megan Williams, using figures drawn from Diocletian's Price Edict. ${ }^{41}$ Though this figure is only an estimate, it still establishes that Origen operated on an entirely different level of magnitude from earlier Christian scholars like Justin and Theodotus. The generous patronage of Ambrose allowed Origen to be massively productive, and to join the ranks of the empire's elite scholars, alongside Africanus.

37 The list is from Origen, Epistula ad Gregorium Thaumaturgum 2.1 (H. Crouzel, ed., Grégoire le Thaumaturge. Remerciement à Origène, suivi de la lettre d'Origène à Grégoire, [Paris 1969]). See also Gregory Thaumaturgus, In Origenem oratio panegyrica, 8.113-14 (Crouzel (above, n.37), and Euseb. Hist. eccl. 6.18.3.

${ }^{38}$ Ambrose: Jer. Ep. 43.1, cf. Epiph. Adv. haeres. 64.3.5. See also Euseb. Hist. eccl. 6.23.1-2 for more on the support provided by Ambrose to Origen. A. M. Castagno ("Origene e Ambrogio: l'indipendenza dell'intellettuale e le pretese del patronato," in L. Perrone, ed., Origeniana Octava. Origen and the Alexandrian Tradition. Papers of the 8th International Origen Congress, Pisa, 27-31 August 2001, Bibliotheca Ephemeridum theologicarum Lovaniensium 164 [Louvain 2003] 1.165-93) provides a thorough review of Origen's relationship with Ambrose.

${ }^{39}$ Ambrose's close involvement in the labors of his client is described by Origen himself in a fragmentarily preserved letter; for the text of this letter, with translation and discussion, see P. Nautin. Lettres et écrivains chrétiens des IIe et IIIe siècles (Paris 1961) 250-53. See also Jer. Ep. 43.1, with the discussion of Nautin (above) 260-61. For Ambrose's input provided to Origen while writing a letter, see Epistula ad Africanum, 24 (M. Harl and N. De Lange, eds., Origène. Sur les Ecritures : Philocalie, 1-20; La lettre à Africanus sur l'histoire de Suzanne [Paris 1983]).

${ }^{40}$ See A. Grafton and M. Williams, Christianity and the Transformation of the Book: Origen, Eusebius, and the Library of Caesarea (Cambridge, Mass., 2006) 105.

${ }^{41}$ See Grafton and Williams (above, n.40) 106. 
In sum, access to large amounts of money provided the basis for the careers of both Africanus and Origen, and for the connections that they gained to the imperial household. Because of their access to money, neither scholar suffered from the educational disadvantages of their earlier counterpart Justin. Africanus and Origen also did not have to deal with the prejudices that had faced Theodotus the leatherworker just a few decades earlier. All four scholars were Christian, but only Africanus and Origen were in positions that allowed them to fit in among elite, non-Christian scholars, as the paper will now demonstrate.

\section{The Politics of Intellectual Life under the Severans}

Access to wealth and education provided a necessary starting point for the careers of Africanus and Origen, but they still needed to be able to live up to mainstream expectations for intellectual life in order to gain connections to the imperial household. It is insufficient to say that Africanus and Origen were able to gain their connections simply because Alexander and his mother Mamaea were sympathetic to Christians, as both Eusebius and the Historia Augusta suggested in the fourth century. ${ }^{42}$ A substantially different and more complicated image of Alexander and Mamaea comes from the work of Herodian, a contemporary reporter. ${ }^{43}$ Herodian reveals that the young emperor and his mother were not in a position where they could flout mainstream expectations for intellectuals, especially following the short and controversial reign of Alexander's predecessor, Elagabalus (218-222). ${ }^{44}$ This emperor, we learn from both Herodian and Cassius Dio, another contemporary reporter, had received the nickname of "Assyrian" for his foreign habits, which included a refusal to eat pork, an unwillingness to wear Greek or Roman clothing, and the heavy-handed introduction to Rome of the

${ }^{42}$ See Euseb. Hist. eccl. 6.21.3-4, 6.28.1; SHA Alex. Sev. 22.4, 29.2, 43.6-7, 45.7, 49.6, 51.7-8.

${ }^{43}$ For a brief overview of Herodian's life and recent scholarship on his work, see H. Sidebottom, "Severan Historiography: Evidence, Patterns, and Arguments," in S. Swain, S. Harrison, and J. Elsner, eds., Severan Culture (Cambridge 2007) 78-82. Note also the discussion of A. M. Kemezis, Greek Narratives of the Roman Empire under the Severans: Cassius Dio, Philostratus and Herodian (Cambridge 2014) 227-72.

${ }^{44}$ For discussion of this emperor's reign, see M. Icks, The Crimes of Elagabalus: The Life and Legacy of Rome's Decadent Boy Emperor (Cambridge, Mass., 2012). 
worship of his god. ${ }^{45}$ Alexander's reign, in contrast, was characterized by a conscious effort on the part of the imperial household to establish that it had transcended its foreign, provincial origins. Herodian reports that Mamaea secured teachers for her son in "all forms of paideia" and ensured that he received a literary education in both Latin and Greek. ${ }^{46}$ All of these efforts were designed as a response to the prejudices of elite Romans towards people of foreign birth, which are quite apparent from the works of both Herodian and Dio. ${ }^{47}$ The image of the Severan dynasty and of Alexander's reign that comes from Herodian and Dio is ultimately incompatible with the simplistic suggestion that the young emperor and his mother were sympathetic to Christianity. Whatever interests they did have in Christianity still had to be compatible with their larger program of fitting in with the prejudicial norms of elite Greek and Roman society. Alexander's reign was consequently not a good time for scholars with nontraditional backgrounds and training to gain connections with the imperial household. The connections gained by Africanus and Origen to the imperial household should therefore not be taken as the inevitable consequence of Severan interests in Christianity, but rather as proof that both scholars were able to fit in with the norms of elite intellectual life. As this section of the paper argues, Africanus and Origen were strikingly similar to their non-Christian counterparts, and they interacted with members of the imperial household in the same ways that non-Christian scholars had for centuries.

\section{A. Africanus}

To take Africanus first, he gained his connection to the imperial household through his participation in an embassy, which provided him-and many other previous scholars who had also served as ambassadorswith an excellent entrée to Rome. A long and distinguished list of

${ }^{45}$ Nickname: Cass. Dio 80(79).11.2. Foreign habits and rites: Hdn. 5.5.4-5; 5.6.46; 5.6.9. On Dio and his work, see the overview of Sidebottom (above, n.43) 74-8, and the full treatment of Kemezis (above, n.43) 90-149.

${ }^{46} \mathrm{Hdn}$. 5.7.5.

${ }^{47}$ For some examples of prejudicial statements about Syrians and others, note Cass. Dio. 78(77).10.2, 79(78).27.1, and 80(79).11.2; Hdn. 1.3.5, 1.6.9, 2.7.9, 4.8.7, 7.1.2. Some signs of the impact of this prejudicial atmosphere are found in the repeated suggestions of the Historia Augusta that Alexander preferred not to be called a Syrian (Alex. Sev. 28.7 ; 38.3-6; 44.3; 64.3), and that he even claimed to be descended from Romans, rather than from Africans and Syrians (Alex. Sev. 44.3). 
scholar-ambassadors can easily be assembled, including Posidonius and Apollonius Molon, who both represented Rhodes in the first century вСE, and the three philosophers of the famous Athenian embassy of 155 всE: Carneades, Critolaus, and Diogenes of Babylon. ${ }^{48}$ Participation in an embassy was all the more valuable for those scholars who represented regions that were very much on the minds of the Roman elite, as was the case for all of these earlier scholars who were active in an age when Rome was still expanding and cementing its power in Greece and the Aegean. Africanus was in a similarly advantageous position serving on his embassy, which had a mission of securing colonial status for the Palestinian village of Emmaus. ${ }^{49}$ The embassy achieved its goal soon before the death of Elagabalus in March 222, and its success came as no real surprise, as its purpose was completely in line with Severan policy in the region. ${ }^{50}$ Sustained imperial attention to the provinces of the Near East had already led to the establishment of numerous colonies there. ${ }^{51}$ Like many scholars before him, Africanus was able to gain the attention of the imperial household because of his participation in an embassy, and there is no reason to believe that his religion was of any relevance to the success of his mission.

Details about Africanus' career after his participation in the embassy are sparse, but he does seem to have gained a position close to Elagabalus' successor Alexander, for whom he took a leading role in the development, and likely even the construction, of a new imperial library. The evidence for Africanus' involvement with this new library comes only from a single passage of his Cesti, a fragmentarily preserved miscellany that he dedicated to the young emperor around $231 . .^{52}$ The reference to the library is preserved on a papyrus found at Oxyrhynchus,

${ }^{48}$ Posidonius: T1a and T28 (L. Edelstein and I. G. Kidd, eds., Posidonius I: The Fragments, ${ }^{2}$ [Cambridge 1989]). Apollonius Molon: Val. Max. 2.2.3. For the three Athenian philosophers, see J. G. F. Powell, "The Embassy of the Three Philosophers to Rome in 155 BC," in C. Kremmydas and K. Tempest, eds., Hellenistic Oratory: Continuity and Change (Oxford 2013) 219-47. For a discussion of sophists who served as ambassadors in the third century CE, see M. Heath, Menander: A Rhetor in Context (Oxford 2004) 279-94.

${ }^{49}$ See Chronographiae, T3 = Syncellus, Ecloga chronographica, 439.15-20.

${ }^{50}$ On the date, see Roberto (above, n.4) 177.

${ }^{51}$ See F. Millar, "The Roman Coloniae of the Near East: A Study of Cultural Relations," in H. M. Cotton and G. M. Rodgers, eds., Rome, the Greek World, and the East, Vol. 3: The Greek World, the Jews, and the East (Chapel Hill 2006) 164-222.

${ }^{52}$ Cesti T3 = Syncellus, Ecloga chronographica, 439.15-20. For the date of the work's composition and dedication, see Roberto (above, n.4) 186-88. 
and it comes in the midst of an odd discussion concerning what Africanus claims is the original incantation used by Odysseus to summon the spirits of the dead in Odyssey $11 .{ }^{53}$ Africanus refers to the places where a reader might find copies of the incantation, one of which was "in Rome near the baths of Alexander in the beautiful library in the Pantheon,

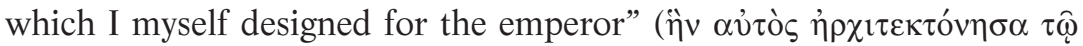
$\Sigma \varepsilon \beta \alpha \sigma \tau \hat{\omega}) .{ }^{54}$ The context of the passage has not inspired complete confidence in Africanus' claims about a library in the Pantheon. This library is unattested in any other literary sources, and no material remains of it have been discovered, although there has been much speculation concerning the so-called "South building" of the Pantheon, the few remains of which are suggestive of some common features in ancient libraries..$^{55}$ Africanus' involvement in the development of the new library's collection is generally granted, on the grounds of his obvious experience with books. ${ }^{56}$ But serious doubts have been cast on Africanus' claim to have constructed the library, so much so that the recent translation of the Cesti by William Adler balks at rendering the verb ó $\rho \chi \imath \varepsilon \varepsilon \kappa \tau$ ové $\omega$ according to its basic transitive sense of designing or constructing. ${ }^{57}$ Africanus is instead presented as the supervisor of the library's construction: "the beautiful library in the Pantheon, the construction of which I personally supervised for the Emperor." ${ }^{58}$ The justification for such doubts rests mostly on Africanus' boastfulness, especially in his Cesti, where he presents himself as someone who possesses expertise in nearly every

${ }^{53}$ Cesti F10 = POxy. 3.412. For a discussion of the papyrus and the history of its interpretation, see J. Hammerstaedt, "Julius Africanus und seine Tätigkeiten im 18. Kestos (P.Oxy. 412 col. II),” in Wallraff and Mecella (above, n. 5) 53-69.

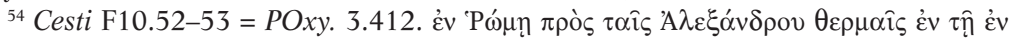

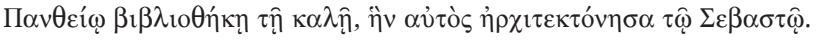

${ }^{55}$ For skepticism about the existence of the library itself, see E. Bowie, "Libraries for the Caesars," in J. König, K. Oikonomopoulou, and G. Woolf, eds., Ancient Libraries (Cambridge 2013) 259 n.109. For speculation about the "South building," which is almost universally identified as Hadrian's Basilica of Neptune, see K. de Fine Licht, The Rotunda in Rome: A Study of Hadrian's Pantheon (Copenhagen 1968) 154-56; F. Coarelli, "Bibliotheca Panthei," in LTUR 1 (1993) 197; G. Graßhoff et al., The Bern Digital Pantheon Project. Plates, Pantheon 2 (Bern 2009) 182, with accompanying figures. Hammerstaedt (above, n.53) 66-67 is more cautious about the library's possible location.

${ }^{56}$ See A. von Harnack, "Julius Afrikanus, der Bibliothekar des Kaisers Alexander Severus,” in G. Leyh, ed., Aufsätze Fritz Milkau gewidmet (Leipzig 1921) 145; Adler (above, n.6) 541.

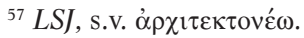

${ }^{58}$ Adler in Walraff (above, n.24) 31. 
imaginable field of study, and this has inspired skepticism that he really was so capable in so many different areas..$^{59}$ But it is worth pointing out that architects were supposed to be masters of many different fields of study, according to Vitruvius, who suggests that an architect "should be lettered, experienced with drawing, and skilled in geometry. He should know much of history, and diligently listen to philosophers. He should understand music and be not ignorant of medicine. He should know the answers of jurists and be familiar with astronomy and its calculations." ${ }^{\circ 0}$ The list of fields mentioned matches up quite well with Africanus' self-presentation of his own expertise in the extant fragments of his works, with the single exception of familiarity with the "answers of jurists," so it is reasonable on these grounds to assume that he could have functioned as an architect. ${ }^{61}$ There is also a brief suggestion in the twelfth-century Chronicle of Michael the Syrian that Africanus "presided over the construction" of the colony of Nicopolis, which was the new name of Emmaus, the village he had represented on his embassy to Rome. ${ }^{62}$ The brevity of this passage and the lateness of its source raises questions about how much it should be trusted, but there are no real difficulties involved in reconciling it with what else we know of Africanus' life; he could well have gone back to Emmaus/Nicopolis after the embassy and then returned to Rome at a later date to take up his place at the court of Alexander. ${ }^{63}$ An interesting parallel for Africanus' possible role as an architect and civic leader comes from the life of Aelius Nicon, the father of Galen, an architect by profession who was also kept busy by civic duties in his native Pergamum. ${ }^{64}$ Speculation about

${ }^{59}$ See Adler (above, n.6) 541.

${ }^{60}$ Vitr. De arch. 1.1.3.

${ }^{61}$ For Africanus' familiarity with geometry and drawing, see Cesti F7.15.1-2, which includes accompanying diagrams of triangles to illustrate his discussion of how to measure the width of a river and the height of a city wall using geometric principles. His historical knowledge is on display throughout the fragments of the Chronographiae. He was identified as a philosopher in the Suda ( $\alpha 4647$ Adler). Medical and veterinary subjects are omnipresent in the Cesti. Astronomical knowledge is on display at Chronographiae F93.67-69. Familiarity with music can likely also be taken for granted, given Africanus' training in geometry and astronomy.

${ }^{62}$ Michael Syrus, Chronicle, 6.7 (113, J. B. Chabot, ed., Chronique de Michel le Syrien, Patriarche Jacobite d'Antioche [Paris 1899-1924]) cited by Adler (above, n.6) 541 n.86.

${ }^{63}$ See Roberto (above, n.4) 178 on the uncertainty surrounding Africanus' travels after the embassy.

${ }^{64}$ See Galen, Aff. dig. 8.3 (Kühn 5.41). 
Africanus' potential involvement in the building of Nicopolis aside, the language that he used to describe the library suggests also that he had some involvement in its construction. A telling parallel for Africanus'

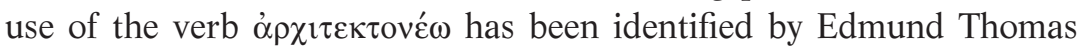
in the Hellenistic military author Bito, who referred to a siege engine "which Posidonius the Macedonian constructed for Alexander the son

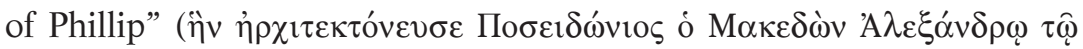
$\Phi \uparrow \lambda i \pi \pi \mathrm{ov}){ }^{65}$ The similar use of the verb in Africanus' passage suggests that the library was something that he built, rather than assembled or collected. A similar impression is provided by the application of the adjective $\kappa \alpha \lambda \eta$ to the library. The word $\beta \imath \beta \lambda_{1} 0 \theta \dot{\eta} \kappa \eta$ was often used by Greek authors to describe a collection of books, rather than a place or building. ${ }^{66}$ But Africanus' claim that his $\beta \beta_{1} \beta \lambda_{10} \theta \eta \dot{\kappa} \kappa$ was $\kappa \alpha \lambda \eta$ suggests that he was referring to the room or building where the books were kept. There have been some claims that the beauty referred to the contents of the library, but these are unconvincing. ${ }^{67}$ The beauty of Africanus' library was instead likely to have derived from other elements in the structure, including its cupboards (armaria) used for the storage of scrolls, which were often made from ivory and valuable types of wood ${ }^{68}$ Statues and a sculptural program would also have contributed to the beauty of the space. Such features were ubiquitous, so much so that a bust or statue of an author almost necessarily accompanied his works in imperial libraries. ${ }^{69}$ If Africanus did design the library of the Pantheon for Alexander, then he surely had a hand in the design and placing of its furniture and sculptural program, in addition to the development of its collection of scrolls.

Africanus' involvement in the new library for Alexander speaks to his closeness to the emperor and to his finding roles for himself at the imperial court that had been held before him by many non-Christian

${ }^{65} \mathrm{E}$. Thomas, Monumentality and the Roman Empire: Architecture in the Antonine Age (Oxford 2007) 296 n.16, citing Bito 4 (C. Wescher, ed., Poliorcétique des Grecs [Paris 1867]).

${ }^{66}$ See C. Jacob, "Fragments of a History of Ancient Libraries," in König (above, n.55) 67.

${ }^{67}$ See Harnack (above, n.56) 145; F. Granger, "Julius Africanus and the Western Text," JThS 35 (1934) 367.

${ }^{68}$ See D. Petrain, "Visual Supplementation and Metonymy in the Roman Public Library," in König (above, n.55) 337-38.

${ }^{69}$ See Petrain (above, n.68) 339-42. 
scholars. The new library, located so prominently in or around the complex of the Pantheon, surely formed part of the larger project to demonstrate Alexander's training in "all forms of paideia." Alexander and his advisors no doubt provided considerable input on the design and contents of the new library, which would have meant working closely with Africanus. All of this is clear from evidence relating to other imperial libraries, which were politicized spaces that had even served in earlier periods as locations for meetings of the Senate, and for the reception of embassies..$^{70}$ Emperors before Alexander had also exerted personal control over the collections and sculptural program of imperial libraries, sometimes simply for reasons of personal taste. Tiberius had ensured that the works and imagines of three erudite and difficult Hellenistic poets were placed in the libraries of Rome; Caligula also apparently contemplated removing the works and imagines of Livy and Vergil from Roman libraries. ${ }^{71}$ Alexander may well have been less demanding than these earlier emperors, but it is still clear that Africanus would have had to liaise with him and to translate his demands and desires for the library into reality. Such tasks would have linked Africanus to a larger group of imperial librarians and architects, who likewise had worked closely with other emperors and similarly risked incurring their disfavor. ${ }^{72}$ Previous imperial librarians included a number of extremely learned scholars, chief among them Varro, Hyginus, and Suetonius, the last of whom also held other important administrative roles. ${ }^{73}$ Imperial architects are less well attested as individuals, but their closeness to the emperor cannot be doubted to judge from comments about their presence in the imperial entourage, and from the specific example of Apollodorus of Damascus, who was famous for the projects he undertook and for his interactions with Trajan and Hadrian. ${ }^{74}$ Africanus' place close to Alexander joined with him a distinguished company of non-Christian scholars.

${ }^{70}$ For discussion and references, see T. K. Dix and G. W. Houston, "Public Libraries in the City of Rome: From the Augustan Age to the Time of Diocletian," MEFRA 118.2 (2006) 683. Note also Petrain (above, n.68) 346 on libraries as "politicized" spaces.

${ }^{71}$ Suet. Tib. 70.2; Calig. 34.2.

${ }^{72}$ See Thomas (above, n.65) 92 for discussion of the "implicit rivalry" between architect and patron.

${ }^{73}$ See Bowie (above, n.55) 244-59 for a review of the evidence concerning imperial librarians.

${ }^{74}$ For architects in the imperial entourage of Hadrian, see Epit. de Caes. 14.4. For

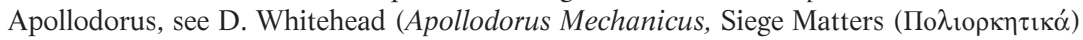


The work that Africanus dedicated to Alexander confirms that Christianity had little to no bearing on the position he gained at the imperial court, and that he fit in well with contemporary intellectual trends. This is the Cesti, which took the form of a miscellany, a popular genre for scholars of all sorts under the Roman Empire, including during the time of the Severans. ${ }^{75}$ Africanus was not the only Christian scholar to use this genre, as is clear from the example of the Stromateis of his contemporary Clement of Alexandria, but his work is distinguished by the complete lack of content relating to Christianity in the substantial fragments of it that survive. The work instead displays the claimed expertise of its author in a wide range of areas, while at the same time demonstrating his mastery of language. Africanus was no pure Atticist, but Attic forms and spellings dot the work, and he delighted also in coining new words and in using rhetorical tropes and figures. ${ }^{76}$ Africanus was even able to offer a memorable example of ekphrasis from his own experiences, describing how Bardesanes (Bardaisan), whom he met at the court of Abgar, was such a talented archer that he was able to create a portrait of a handsome youth with his arrows, shooting them at a shield held up by his subject. ${ }^{77}$ It was evidently irrelevant that Bardesanes was also a distinguished Christian scholar, since Africanus simply identified him as a Parthian. ${ }^{78}$ This silence about Bardesanes is suggestive that Christianity had no real place in the Cesti, and that Africanus' own Christianity had no relevance for the position that he held at the court of Alexander.

Overall, there is no reason to believe that Africanus' career at Rome provides any support to the claim that Alexander had any great sympathy for Christianity. Africanus found a place for himself at the court of Alexander that differed little from the places held by earlier, non-Christian scholars. He also fit in well with contemporary intellectual trends.

[Stuttgart 2010]), with an overview of his life, and an edition and translation of a work on siege-craft that he may have written, and dedicated either to Trajan or Hadrian.

${ }^{75}$ For the Severan period in general, see J. König and T. Whitmarsh, "Ordering Knowledge," in J. König and T. Whitmarsh, eds., Ordering Knowledge in the Roman Empire (Cambridge 2007) 3-39; T. Whitmarsh, "Prose Literature and the Severan Dynasty," in Swain, Harrison, and Elsner (above, n.43) 44-49.

${ }^{76}$ See Roberto (above, n.4) 43; Walraff (above, n.24) xxv-xxvi.

${ }^{77}$ Cesti F12.20.35-47.

${ }^{78}$ Cesti F12.20.25. For the life and work of Bardesanes, see J. J. W. Drijvers, Bardai an of Edessa (Assen 1966). 
Ultimately, Africanus' range and skill as a scholar provide some confirmation to Eusebius' claim that he was "a learned man known to

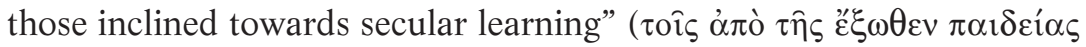
op $\mu \omega \mu \varepsilon ́ v o r \varsigma) .{ }^{79}$ His career at Rome serves as a demonstration not of any new Severan interest in Christianity, but rather of his ability as a Christian scholar to conform himself to established expectations for scholarly behavior.

\section{B. Origen}

Africanus' associate Origen presents a more complicated case. His interactions with the imperial household were much less extended than those of Africanus. Origen only met relatively briefly in 231-232 with Mamaea. ${ }^{80}$ And this meeting was more explicitly religious in character than the interactions that Africanus had with Alexander at Rome. But Origen still seems to have carried himself in his meetings with Mamaea in a way that would have been familiar to her from her interactions with non-Christian scholars. Origen ultimately fit quite well within the world of Philostratus' sophists. He may even have been especially similar to one famous sophist, Favorinus of Arles, if the rumors about a rash act committed in his youth are true.

Our one surviving account of Origen's meeting in Antioch with Mamaea is a brief report in Eusebius, which leaves much unsaid about its nature and which is characterized also by a certain amount of defensiveness that it even took place. ${ }^{81}$ This defensiveness came from Origen himself, whose own account of the meeting in a now-lost autobiographical letter was the source of Eusebius' information, according to the arguments of Nautin. ${ }^{82}$ The report emphasized that the meeting was primarily of a religious character. Mamaea is described as "an exceptionally religious woman," and she wished to test Origen's "knowledge of divine

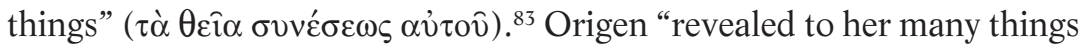
relating to the glory of the lord and the excellence of divine teaching"

${ }^{79}$ Cesti T2 = Euseb. Quaestiones evangelicae, apud Nicetas of Heraclea, Catena in Lucam ( $P G$ 22,965AB). For similar comments on Africanus' learning, see Euseb. Praep. evang. 10.9.26; Socrates, Hist. eccl. 2.35.10.

${ }^{80}$ See Nautin (above, n.31) 68-69 for the date.

${ }^{81}$ Euseb. Hist. eccl. 6.21.3-4.

${ }^{82}$ Nautin (above, n.31) 56-57.

${ }^{83}$ Euseb. Hist. eccl. 6.21.3. 
before he "hurried back to his normal pursuits." ${ }^{84}$ The letter emphasized also that he was summoned to Antioch by Mamaea and accompanied by a military escort..$^{85}$ The same factor was mentioned in the report concerning Origen's earlier meeting with the Roman governor of Arabia: "A certain solider arrived bearing letters to Demetrius the bishop of the region and to the current prefect of Egypt from the governor of Arabia, [asking] that they send Origen with all haste to converse with him." ${ }^{86}$ As the son of a martyr and the teacher of many pupils who had been martyred, Origen was careful to make clear that his encounters with the imperial household and a Roman governor were not the result of his own choice. Origen was evidently less eager than Africanus to cultivate imperial connections.

But other sources suggest that Origen's behavior in Antioch would have corresponded closely to what Mamaea would have expected from any sufficiently distinguished non-Christian scholar. We gain insight into Origen's scholarly demeanor especially from a letter he wrote concerning his actions during what may have been the same visit to Antioch. ${ }^{87}$ The relevant portion of the letter is extant only in a Latin translation by Rufinus. ${ }^{88}$ Even in its translated form, the story reported would not be out of place in Philostratus' Lives of the Sophists, or Galen's On My Own Books. Origen described his encounter with a "certain heretic" in Ephesus, and how this man had later forged a work that he claimed to be the record of a debate between himself and Origen, though such a debate had never taken place. The heretic then distributed the document widely: "I indeed know that he sent it to those who were at Rome, but I do not doubt that he sent it to others in different places." ${ }^{89}$ Origen confronted the heretic at Antioch, where he claimed to have "refuted him in front of many onlookers" (multis eum praesentibus argui).$^{90}$ In their

\footnotetext{
${ }^{84}$ Euseb. Hist. eccl. 6.21.4.

${ }^{85}$ Euseb. Hist. eccl. 6.21.4.

${ }^{86}$ Euseb. Hist. eccl. 6.19.15.

87 The letter was directed to "his friends in Alexandria." Nautin (above, n.31) 41112, 436 favors a later date for the letter and for Origen's visit to Antioch. R. Amacker and É. Junod (Pamphile et Eusèbe de Césarée: Apologie pour Origène, suivi de Rufin d'Aquilée: Sur la falsification des livres d'Origéne [Paris 2002] 35-38) present arguments in support

${ }^{88}$ Rufinus, De adulteratione librorum Origenis, 7; Amacker (above, n.87).

${ }^{89}$ Rufinus, De adulteratione librorum Origenis, 7.54-55.

${ }^{90}$ Rufinus, De adulteratione librorum Origenis, 7.58-59.
} of an earlier date. 
public confrontation, the heretic was unwilling to produce the debate that he had forged, so that the audience would have the opportunity to recognize Origen's style. The heretic was thus "found guilty by everyone and convicted of falsehood" (conuictus ab omnibus et confutatus est falsitatis). ${ }^{91}$ The free movement and communication between Ephesus, Antioch, and Rome evokes the wide-ranging travels of Philostratus' sophists, as does the dramatic public debate between Origen and the heretic. ${ }^{92}$ A comparable example comes from the rivalry between Herodes Atticus and Philagrus of Cilicia in the second century and the memorable occasion when Herodes' pupils were able to prove that Philagrus was guilty of repeating the same declamations that he pretended were improvised on the spot. Herodes' pupils acquired a copy of a declamation that Philagrus had already given in Asia and then asked him at Athens to declaim on the same theme. When Philagrus began to speak, Herodes' pupils read his previous composition alongside him, which resulted in "laughter and a great din" and the verdict from the assembled audience that he stood convicted of the charge leveled against him. ${ }^{93}$ Origen's request that the audience authenticate his treatise recalls also the famous story told by Galen of an encounter he witnessed in a Roman bookshop: after reading only the first two lines, a grammarian dismissed as a forgery a treatise for sale which was represented as a work by "Galen the doctor." ${ }^{4}$ Origen's handling of this controversy is suggestive of a confident and even slightly histrionic attitude in his public demeanor. His time in Antioch in 231-232 with Mamaea likely also involved continued work on his massive commentary on the Gospel of John, which he had set aside when he left Alexandria. ${ }^{95}$ Such an effort would have been a demonstration to Mamaea that her summons would not keep him away from his work, and it was completely in keeping with the attitude of a philosopher trying to demonstrate that imperial attention had no real impact on him. ${ }^{96}$ Behavior of this sort would have been

${ }^{91}$ Rufinus, De adulteratione librorum Origenis, 7.63-64.

${ }^{92}$ For the mobility of sophists, see G. W. Bowersock, Greek Sophists in the Roman Empire (Oxford 1969) 109. For a discussion of the cities frequented by sophists, see E. Bowie, "The Geography of the Second Sophistic: Cultural Variations," in B. E. Borg, ed., Paideia: The World of the Second Sophistic (Berlin 2004) 65-83.

${ }^{93}$ Philostr. V S 2.8 (579).

${ }^{94}$ Gal. Libr. Propr. Prol. 1-3 (Kühn 19.8-9).

${ }^{95}$ Nautin (above, n.31) 367-68.

${ }^{96}$ See McLynn (above, n.5) 186. 
completely familiar to Mamaea; she would no doubt even have been surprised if Origen had acted any differently.

Origen's encounter with Mamaea also gave him an opportunity to demonstrate his skill as an extemporaneous speaker, another area where he conformed to prevailing expectations for scholarly behavior. Origen's skills as an extemporaneous speaker were emphasized by his later defenders, such as Pamphilus, who suggested that he spoke off the cuff on an almost daily basis in church (paene cotidie in Ecclesia . . . ex tempore) ${ }^{97}$ Small pieces of his extemporaneous output survive in the form of homilies, which were copied down by shorthand writers. ${ }^{98}$ Most of these homilies are extant only in Latin translations made by Rufinus and Jerome, but the small collection of Greek homilies has recently been expanded with twenty-nine new works, thanks to the discovery in 2012 of a manuscript in Munich that had previously been misidentified. ${ }^{99}$ Three of these new homilies are explicitly identified in the manuscript as being extemporaneous productions. ${ }^{100}$ These new pieces of evidence join a few other explicit signs in the older body of homilies that clearly identify them as unrehearsed works. One telling example is Origen's fifth homily on First Samuel: the selection read from scripture was sufficiently long

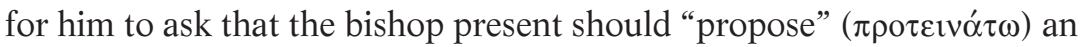
aspect from it that he should discuss. ${ }^{101}$ The situation outlined here may not correspond exactly to the familiar motif in the works of Philostratus and Galen, where a speaker would offer an extemporaneous speech on

${ }^{97}$ Pamphilus, Apologeticum sancti Pamphili martyris pro Origene, 9; Amacker and Junod (above, n.87). Only the first book of this work survives, and only in a translation by Rufinus.

${ }^{98}$ See Euseb. Hist. eccl. 6.36.1. Nautin (above, n.31) 389-409 rejects Eusebius' suggestion that Origen only began giving homilies at the age of sixty, and offers his own chronology. See also A. M. Castagno, Origene predicatore e il suo pubblico (Milan 1987) 50-64.

${ }^{99}$ For details on the discovery, see M. M. Pradel, "Novità origeniane dalla Staatsbibliothek di Monaco di Baviera: il Cod.graec. 314,” Adamantius 18 (2012) 16-40; L. Perrone, "Rediscovering Origen Today: First Impressions of the New Collection of Homilies on the Psalms in the Codex monacensis Graecus 314," SP 56 (2013) 103-22; L. Perrone, "Origenes rediuiuus: la découverte des Homélies sur les Psaumes dans le Cod. Gr. 314 de Munich," (2013) 55-93. The new homilies have now been published in full, but I was unable to access the new edition before work on this article was already substantially completed: L. Perrone, ed., Origenes XIII. Die neuen Psalmenhomilien: eine kritische Edition des Codex monacensis graecus 314 (Berlin and Boston 2015).

100 See Perrone, "Origenes rediuiuus" (above, n.99) 84.

${ }^{101}$ Origen, Homilia V in I Reg. [I Sam.], 1.22-23 (P. Nautin and M.-T. Nautin, eds., Origène. Homélies sur Samuel [Paris 1986]). 
a subject proposed by an audience member. ${ }^{102}$ The verb for proposing used by Origen was $\pi \rho \tau_{\varepsilon i v} \omega$ rather than $\pi \rho \circ \beta \alpha ́ \lambda \lambda \omega$, which we might have expected to see instead. ${ }^{103}$ Origen was nonetheless completely able to replicate this characteristic behavior of sophists and iatro-sophists, even if he did so in a slightly different setting. Once again, Mamaea would have expected as much, and Origen no doubt demonstrated to her that he was up to the challenge of extemporaneous speech.

There is also one final element of Origen's self-presentation as a speaker that would no doubt have had a major impact on Mamaea: this is his self-castration, an act that he allegedly performed in a moment of rashness in his youth. As Eusebius reported, Origen apparently took the advice of Matthew 19:12 "too literally and excessively": "There are eunuchs who made themselves eunuchs for the sake of the kingdom of the heavens." ${ }^{104}$ Many scholars now insist that Origen committed no such act, and they point to the interpretation he offered later in life of this same passage from scripture, where he suggests that no one should literally castrate himself for the sake of the kingdom of heaven. ${ }^{105}$ But the controversy about Origen's castration will not go away, and a recent review of the issue by Christoph Markschies concludes that the reliability of the story can neither be guaranteed nor dismissed completely. ${ }^{106}$ For the sake of argument, I will assume here that Origen did castrate himself. From the perspective of Mamaea, Origen would then have seemed something like a latter-day Favorinus of Arles, the famous philosopher-sophist active in the second century who was born without testicles and who had a prominent place in Philostratus' Lives of the Sophists. ${ }^{107}$ Like Favorinus, Origen may well have lacked many of the defining masculine characteristics that were so significant for sophists and other elite men. But he would have made up for their lack with his wide learning and his

${ }^{102}$ See H. von Staden, "Galen and the Second Sophistic," in R. Sorabji, ed., Aristotle and After (London 1997) 40-44.

${ }^{103}$ See Staden (above, n.102) 42-44 for examples.

${ }^{104}$ Euseb. Hist. eccl. 6.8.1.

${ }^{105}$ Commentarium in evangelium Matthaei 15.1-4 (H. J. Vogt, ed., Origenes. Der Kommentar zum Evangelium nach Mattäus, Bibliothek der griechischen Literatur 18, 30, 38 [Stuttgart 1983-93]). For an extensive review of scholarship relating to the castration of Origen, see C. Markschies, "Kastration und Magenprobleme? Einige neue Blicke auf das asketische Leben des Origenes," in Origenes und sein Erbe: Gesammelte Studien, TU 160 (Berlin and New York 2007) 15-22.

${ }^{106}$ Markschies (above, n.105) 34.

${ }^{107}$ See Philostr. VS 1.8 (489-92). 
undoubted confidence as a speaker, just as Maud Gleason has suggested in the case of Favorinus. ${ }^{108}$ The impact of castration on Origen's body and voice may have made him into a more fascinating speaker and provided another boost to the reputation that he gained as a scholar. ${ }^{109}$ By the time of his meeting with Mamaea, Origen was a well-travelled and prolific scholar thanks to the help of Ambrose, and he had already been summoned by the Roman governor of Arabia. ${ }^{110}$ If the story of Origen's castration is true and the impact of his rash act was visible on his body, then it may be reasonable to believe that Mamaea knew all this when she summoned him. Castrated or not, Origen undoubtedly had a "big public reputation" worthy of a sophist. ${ }^{11}$

Compared to Africanus, Origen had a substantially different experience in his interactions with the imperial household. He had only a brief encounter with Mamaea, and he met her in Antioch rather than in Rome. His meeting with Mamaea, however, was a direct consequence of his education and access to wealth and of the reputation that he had gained as a scholar even in mainstream circles. This encounter with Mamaea gave Origen an opportunity to display his skills as an extemporaneous speaker and to establish that he was not overly impressed to be summoned by a member of the imperial household. Ultimately, Origen was never a good candidate to take up a more permanent role at the imperial court. He lacked Africanus' elite background, and was little inclined to forget that his father and many of his pupils had been martyred in an earlier persecution. But Origen still was able to conduct himself like his contemporary sophists, and he no doubt proved that this was the case in his brief interactions with Mamaea.

\section{Conclusion}

The careers of Africanus and Origen under the Severans help to illustrate the extent to which Christian scholars were gaining legitimacy

${ }^{108}$ See M. Gleason, Making Men: Sophists and Self-Presentation in Ancient Rome (Princeton 1995) 131-58.

${ }^{109}$ See Markschies (above, n.105) 31-34 for discussion of the varying impact of castration on men in more recent periods: a high voice is not an inevitable result.

${ }^{110}$ See Euseb. Hist. eccl. 6.19.15, and the chronological table in Nautin (above, n.31) 409-12.

111 The quoted phrase is from Bowersock (above, n.92) 13. 
among non-Christians. Their interactions with the imperial household should be taken not as a consequence of the growing "syncretism" of the age or even of the sympathy of Alexander and Mamaea for Christianity, but rather as a sign that Christian scholars had arrived as mainstream figures. Christian scholars in previous periods would have been all too happy to gain connections to the imperial household, as is clear from the example of Justin Martyr and his school. What prevented them from achieving their goal, however, was not because earlier emperors and members of their households were insufficiently sympathetic to Christianity. ${ }^{112}$ Rather, their failures to gain imperial connections were a consequence of their often limited educations and their nonelite backgrounds, and their consequent inability to fit in with the empire's elite scholars. In contrast, the connections that Africanus and Origen gained to the imperial household under the Severans were based on the wealth that had funded their education and their activities as scholars, and also on their ability to act according to the norms of elite intellectual life. By the time of the Severans, the former gap that separated Christian and non-Christian scholars had narrowed, and the recognition of Africanus and Origen by the imperial household was an indisputable sign of the increasing intellectual respectability of Christians in the third century, and not simply of a change in imperial attitudes towards Christianity.

WASHINGTON STATE UNIVERSITY jared.secord@wsu.edu

${ }^{112}$ Note the example of Marcia, the concubine of Commodus, who favored an elderly Christian presbyter named Hyacinthus, about whom nothing else is known. See [Hippol.] Haer. 9.12.10-12. 